\title{
Detection and distribution of ostreid herpesvirus 1 in experimentally infected Pacific oyster spat
}

\author{
Segarra Amélie ${ }^{1}$, Baillon Laury ${ }^{1}$, Faury Nicole ${ }^{1}$, Tourbiez Delphine ${ }^{1}$, Renault Tristan ${ }^{1,{ }^{*}}$
}

${ }^{1}$ Ifremer (Institut Français de Recherche pour l'Exploitation de la Mer), Unité Santé, Génétique et Microbiologie des Mollusques (SG2M), Laboratoire de Génétique et Pathologie des Mollusques Marins (LGPMM), Avenue de Mus de Loup, 17390 La Tremblade, France

*Corresponding author : Tristan Renault, email address : Tristan.Renault@ifremer.fr

\begin{abstract}
:
High mortality rates are reported in spat and larvae of Pacific oyster Crassostrea gigas and associated with ostreid herpesvirus 1 (OsHV-1) detection in France. Although the viral infection has been experimentally reproduced in oyster larvae and spat, little knowledge is currently available concerning the viral entry and its distribution in organs and tissues. This study compares OsHV-1 DNA and RNA detection and localization in experimentally infected oysters using two virus doses: a low dose that did not induce any mortality and a high dose inducing high mortality. Real time PCR demonstrated significant differences in terms of viral DNA amounts between the two virus doses. RNA transcripts were detected in oysters receiving the highest dose of viral suspension whereas no transcript was observed in oysters injected with the low dose. This study also allowed observing kinetics of viral DNA and RNA detection in different tissues of oyster spat. Finally, viral detection was significantly different in function of tissues $(p<0.005)$, time $(p<0.005)$ with an interaction between tissues and time $(p<0.005)$ for each probe.
\end{abstract}

\section{Graphical abstract}

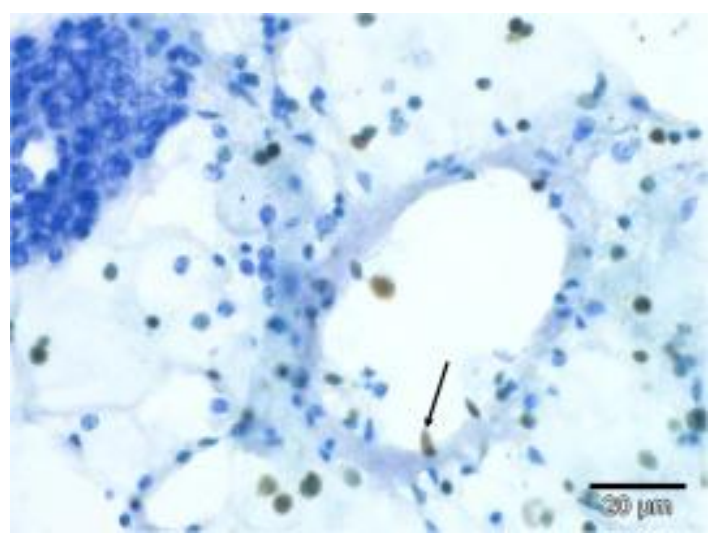




\section{Highlights}

- Viral DNA/RNA localization were studied in oysters by ISH using two virus doses. Viral replication was not detected in oysters receiving the lowest virus dose. Virus was mainly observed in mantle, gills and heart by ISH using the highest dose. Viral detection was significantly different in function of tissues and time.

Keywords : Crassostrea gigas ; In situ hybridization ; Ostreid herpesvirus 1 ; Viral DNA ; Viral RNA 


\section{Introduction}

In France, ostreid herpesvirus 1 (OsHV-1) detection is associated with high mortality rates in Pacific oyster Crassostrea gigas spat (Garcia et al., 2011; Renault et al., 1994). OsHV-1 is a double strand DNA virus which belongs to Malacoherpesvirus family (Davison et al., 2005). Studies have been achieved based on the development of molecular diagnosis assays including PCR and in situ hybridization in order to detect and localize OsHV-1 in C. gigas (Burge and Friedman, 2012; Pepin et al., 2008; Barbosa-Solomieu et al., 2004;). Recently, an in situ hybridization (ISH) technique using Digoxigenin (Dig)-labeled RNA probes was developed in order to provide information concerning the expression of three OsHV-1 genes in $C$. gigas tissues 26 hours post infection (hpi) (Corbeil et al., 2015). ISH is a suited method for DNA and RNA detection in virus infected cells and it has been applied to viral disease diagnosis in aquatic organisms (Huang et al., 2004; Kleeman and Adlard, 2000; Walton et al., 1999). Although OsHV-1 has been investigated for the past decade, several aspects of pathogenesis still need to be clarified such as the viral entry, sites where viral replication occurs initially and distribution of virus in persistent or acute infection. Clarification of these aspects could provide a better understanding about OsHV-1 infection and why some oysters do not develop the infection and do not demonstrate mortality. Arzul and co-workers (2002) have reported the detection of viral DNA and proteins in asymptomatic $C$. gigas collected in the field and suggested that the virus is able to persist in host after primary infection without inducing mortality. More recently, Segarra and collaborators (2014b) reported the detection of viral DNA and RNA in infected oysters with or without associated mortality. Nevertheless, OsHV-1 latency has not been characterized by latencyassociated transcripts (LATs) unlike vertebrate herpesviruses (Jones, 2003). A 
protocol based on intramuscular injection of OsHV-1 suspension was recently developed (Schikorski et al., 2011) that allowed reproduction of the virus in experimental conditions in Pacific oyster spat. This approach appears as a valuable tool to better understand interactions between the virus and its host.

The major aim of this study was to localize virus DNA and RNA in tissues of C. gigas during an experimental infection in Pacific oyster spat. This study also investigated the OsHV-1 detection (DNA and RNA) in animals injected with high or low infection levels. For this purpose, two doses of a viral suspension were tested: a high dose $(H)$ with associated mortality and a low dose (L) without mortality. The infection system used was based on intra-muscular injection of a viral suspension to obtain a synchronous infection among individuals. Collections at several time points and using in situ DNA and RNA hybridization and the kinetics of OsHV-1 replication were explored. Tissue distribution of viral DNA and RNA on histological sections might help to localize early replication sites and understand the replication kinetics.

\section{Material and methods}

\section{Animals and experimental infection using two viral doses}

Pacific oysters Crassostrea gigas were produced during summer 2012 at the Ifremer hatchery in La Tremblade (Charente Maritime, France). Eighty spat oysters (9 month old, $3 \mathrm{~cm}$ in length) were "anesthetized" before injection of the viral suspension (Schikorski et al., 2011). One hundred $\mu \mathrm{L}$ of a low dose of OsHV-1 ( $\mu$ Var, (Segarra et al., 2010)) at $10^{1}$ copies of viral DNA/ $\mu \mathrm{L}$ ( $\mathrm{L}$ dose, $10^{3}$ viral DNA copies per oyster) or 
a high dose of OsHV-1 at $10^{6}$ copies of viral DNA/ $\mu \mathrm{L}\left(\mathrm{H}\right.$ dose, $10^{8}$ viral DNA copies per oyster) were injected into the adductor muscle in the hemolymphatic sinus of 40 oysters per conditions using a $1-\mathrm{mL}$ syringe. The low dose was selected to avoid mortality based on preliminary tests (data not shown) whereas the high dose was chosen to induce mortality. Oysters were then placed in three aquaria per dose (10 oysters per tank) containing $5 \mathrm{~L}$ of filtered seawater at $22^{\circ} \mathrm{C}$ for the sampling. Oyster mortality was monitored daily during 96 hours post infection (hpi) and survival was defined for the two viral doses $(\mathrm{L}$ and $\mathrm{H})$ in two other tanks (10 oysters per tank and per condition).

\section{Total DNA extraction and real time PCR analysis}

Samples were collected 2, 6, 10, 14 and $28 \mathrm{hpi}$ for both viral doses. At each time of collection, 2 oysters were sampled from each tank (6 oysters per time per condition). A piece of mantle was sampled from each individual. DNA extraction was then performed with QiAamp tissue mini kit ${ }^{\circledR}$ (QIAgen) according to the manufacturer's protocol. Elution was performed in $100 \mu \mathrm{L}$ of $\mathrm{AE}$ buffer provided in the kit. The detection and quantification of OsHV-1 DNA was carried out using real-time PCR (Pepin et al., 2008). The amplifications were performed using Mx3000P real-time PCR thermocycler (Agilent) to the following conditions: 1 cycle at $95^{\circ} \mathrm{C}$ for $3 \mathrm{~min}, 40$ cycles of amplification at $95^{\circ} \mathrm{C}$ for $5 \mathrm{~s}, 60^{\circ} \mathrm{C}$ for $20 \mathrm{~s}$. DNA was diluted at $5 \mathrm{ng} / \mu \mathrm{L}$. Five $\mu \mathrm{L}$ of diluted DNA were added to the reaction mix composed of $10 \mu \mathrm{L}$ of Brilliant III Ultra-Fast SYBR QPCR Master Mix (Agilent), $2 \mu \mathrm{L}$ of each primer OsHVDPFor (Forward) 5'-ATTGATGATGTGGATAATCTGTG-3' and OsHVDPRev (Reverse) 5'GGTAAATACCATTGGTCTTGTTCC-3' (Webb et al., 2007) at the final concentration 
of $500 \mathrm{nM}$ each and $1 \mu \mathrm{L}$ of distilled water. Assays included a standard curve and a negative control.

\section{In situ hybridization (ISH)}

ISH was performed adapting a protocol previously described by Renault and Lipart (Renault and Lipart, 1998). In the present study, several ISH approaches were performed: ISH using a DNA probe and ISH using two different RNA probes described by Corbeil et al. (2015). C2/C6 (C2: CTTTTTACCATGAAGATACCCACC and C6: GTGCACGGCTTACCATTTTT), ORF 7 (ORF 7-1: GGCATTCACCCCTGACTCTA and ORF 7-2: CTGGAAGATGGGTTTCTCCA) and ORF 87 (ORF 87-1: GGTGGCCACACAAGAACAAT and ORF 87-2: GGTGGCAGGCACATCTATCT) probes (sense SP6 and anti-sense T7) were synthetized by incorporation of Digoxigenin-11-dUTP (Roche) as described by Corbeil et al. (2015). The C2/C6 probe was used to detect viral DNA. ORF 7 contains motifs $\mathrm{V}$ and $\mathrm{VI}$ characteristic of SF2 helicases and ORF 87 encodes BIR protein. These two viral genes were selected to search for virus RNAs as they have been previously detected in experimentally infected spat (Segarra et al., 2014a) and could be potentially involved in early stages of the viral cycle.

Oysters were fixed for $48 \mathrm{~h}$ in Davison fixative (22\% formaldehyde, $33 \%$ ethanol 95 , $12 \%$ glycerol, $33 \%$ of $0.2 \mu \mathrm{m}$ filtered seawater and $10 \%$ acetic acid). After embedding in paraffin wax, formalin-fixed tissues were sectioned $(7 \mu \mathrm{m})$ and cross sections were collected onto silane-coated slides (Sigma). Histological cross sections were hybridized with $125 \mu \mathrm{L}$ of hybridization buffer (4X SSC, $50 \%$ deionised formamide, $10 \%$ dextran sulfate, $1 X$ Denhardt's solution, $250 \mu \mathrm{g} / \mathrm{mL}$ yeast t-RNA). 
131 The DNA probe was used at the final concentration of $2.5 \mathrm{ng} / \mu \mathrm{L}$ in hybridization 132 buffer, RNA probes were used at $250 \mathrm{ng} / \mathrm{mL}$. Sections and DNA probe (no RNA)

151 Kaplan-Meier (Kaplan and Meier, 1958) survival curves were used to compare were denatured in hybridization buffer at $95^{\circ} \mathrm{C}$ for $5 \mathrm{~min}$. Histological section and RNA probes were not denatured before hybridization. Hybridization was carried out at $42^{\circ} \mathrm{C}$ overnight in a humid chamber. After washing in $1 \mathrm{X}$ SSC with additional $0.2 \%$ BSA for 10 min, sections were incubated in 1X PBS containing $6 \%$ milk protein (Regilait@) for $30 \mathrm{~min}$ at room temperature. Linked probes were detected with antiDigoxigenin-POD, Fab' fragments from sheep (Roche) diluted 1:50 in 1X PBS during 1 hour at room temperature. After five washes in $1 \mathrm{X}$ PBS, the revelation of the antibody was performed with $3^{\prime}$-Diaminobenzidine tetrahydrochloride TAB (Sigma) in the dark at room temperature (10 min). The reaction was stopped with distilled water. Sections were stained for $20 \mathrm{~s}$ in Unna blue and dehydrated, cleared with xylene and mounted for microscopy observation. DNA in situ hybridization was also carried out on non-denatured histological sections in order to control for the absence of single stranded DNA. With RNA probes, this step was omitted as target RNAs and RNA probes are single strand. Moreover, for each targeted RNA, both sense and antisense probes were tested on histological sections in order to confirm hybridization specificity.

\section{Statistical analysis} survival between infected oysters with the low $(\mathrm{L})$ and the high $(\mathrm{H})$ viral suspension

doses. One way analysis of variation (ANOVA) was used to compare quantity of viral DNA (log-transformed) from low and high viral suspension doses. Statistical analyses 
155 were performed using Minitab 16.2.1 statistical software. An ordinal logistic 156 regression model was built to describe the relationship between the viral detection, 157 the time and tissues for each probe. Then, contrast statement (Nichols, 1997) was 158 performed to compare the viral detection level between tissues. A contrast is a linear 159 combination of variables whose coefficients add up to zero, allowing comparison of 160 different tissues. Analyses were carried out using the Statistical Package for the 161 Social Sciences (SPSS, v.23). Results were declared statistically significant at the 162 two-sided $5 \%$ (ie, $p<0.05$ ).

\section{Results}

\section{Oyster survival and viral DNA detection by real-time PCR}

Oyster mortality was daily monitored and Kaplan-Meier survival curves were generated for the low $(\mathrm{L})$ and the high $(\mathrm{H})$ viral suspension doses. No mortality was occrured for the $L$ group during the monitoring period. Oyster survival injected with the dose $\mathrm{H}$ was $30 \%$ at $48 \mathrm{hpi}, 90 \%$ at $72 \mathrm{hpi}$ and $100 \%$ at $96 \mathrm{hpi}$ (Figure 1). The mean viral DNA amounts increased gradually during the infection for both doses, $\mathrm{L}$ and $\mathrm{H}$ (Figure 2). Nevertheless, viral DNA amounts were significantly different

172 (ANOVA, $p<0.05$ ) between the doses. OsHV-1 DNA amounts ranged from 0.5 to 5.73 $173 \times 10^{1}$ and $1.2 \times 10^{2}$ to $7.7 \times 10^{5}$ viral DNA copies per ng of total DNA between 2 and 28 hpi for doses $L$ and $H$, respectively (Figure 2). The viral amounts plateaued after

17512 hpi for the L group (Figure 2).

\section{Viral DNA and RNA detection using in situ hybridization}


178 In order to observe the tissue distribution of OsHV-1, viral DNA and RNA were 179 detected by ISH during the experimental infection. No viral DNA and RNA signals were detected during the study for animals receiving the dose $L$ (Figure 3).

181

The intensity of hybridization signal for the dose $\mathrm{H}$ varied among time, tissues and probes (Table 1). Ordinal logistic regression test was performed for each probe (DNA, RNA ORF 7, RNA ORF 87) and viral detection was significantly different in function of tissues $(p<0.005)$, time $(p<0.005)$ with an interaction between tissues and time $(p<0.005)$. Then, the viral detection level between tissues was compared using contrast test.

Positive hybridization with the DNA probe was observed in connective tissues of mantle and digestive gland at 6 hpi (Table 1). DNA signals were mainly observed in mantle (Figure 4a), gills and heart (Figure 4b). No significant difference (contrast test) was observed between the heart and hemolymph sinus (Figure 4c) and mantle, and between the heart and gills (Table 2). Nevertheless, significant differences were reported between heart and other tissues (e.g adductor muscle $(p<0)$, digestive gland $(p<0.001)$, and gonad $(p<0))$ during infection (Table 2). Statistically significant differences were found also between gills and gonad $(p<0)$, gills and adductor muscle $(p<0)$, gills and digestive gland $(p<0.012)$, and gills and mantle $(p<0.002)$ (Table 2$)$. Gonad, adductor muscle and digestive gland showed lower DNA detection than the mantle, gills and heart. No significant difference was observed between gonad connective tissue (Figure 4d), adductor muscle and the digestive gland (Table 2).

Differences in viral RNA detection were reported depending on collection time and tissues. No RNA detection was observed in gonadal connective tissues using ORF 7 and ORF 87 (Table 1). Positive signals were detected at $14 \mathrm{hpi}$ in mantle, gill and 
202 heart using ORF 7 RNA probe (Table 1). RNA signals detected in the mantle (Figure

203 5) and heart were significantly differents of other tissues (Table 2).

204 First transcripts were detected only at 28 hpi with the ORF 87 RNA probe (Table 1).

205 No significant difference was found between mantle, gills, heart and adductor muscle 206 using the ORF 87 RNA probe (Table 2). Nevertheless, a significant difference was 207 found between mantle and the digestive gland $(p<0.007)$, mantle and gonad 208 ( $p<0.012)$, heart and digestive gland $(p<0.022)$, heart and gonad $(p<0.032)$, gills and 209 gonad $(p<0.047)$ and digestive gland and gills $(p<0.031)$ (Table 2$)$. No discrete 210 signals were present when ORF 7 and ORF 87 sense probe (identical sequence as 211 virus mRNAs) were reacted with infected oyster tissues.

\section{Discussion}

214 Significant differences in terms of mortality rate and viral DNA detection were observed between the two viral doses. Although no mortality was reported in oysters receiving the lowest dose, all oysters injected with the highest dose had died by 96

217 hpi. Viral replication appeared less important for the dose $L$ than the dose $H$ based 218 on real-time PCR. Some authors (Oden et al., 2011; Sauvage et al., 2009) previously 219 reported that viral DNA copies up to $10^{4}$ found in naturally infected oysters could be 220 interpreted as evidence of an expressed viral infection leading to mass mortality. In 221 another study, Renault et al. (2014) noted that up to $10^{4}$ copies of viral DNA per mg 222 of wet tissues were only detected a few days before mass mortality occurred in the 223 field. 
Viral DNA detection was positive by real-time PCR whereas viral RNA and DNA detection were negative on histological sections by ISH for Pacific oyster spat infected with the lowest dose (L). These results could be partly explained through the higher sensitivity of real-time PCR in comparison with ISH (Biesaga et al., 2012). Viral DNA and proteins have been previously reported in adult oysters in absence of mortality (Arzul et al., 2002). Although no mortality was observed 96 hpi after injection of the lowest dose of viral suspension, the increasing level of viral DNA detected by real-time PCR during the course of the experiment suggested that OsHV-1 replicated in oysters receiving this dose. Chaves et al. (2011) showed that an adequate infectious dose is critical in reproducing the clinical infection of avian influenza A virus $(\mathrm{H} 7 \mathrm{~N} 1)$ in chickens. These authors concluded that chickens exposed to lower doses can be infected and shed virus representing a risk for the dissemination of the viral agent (Chaves et al., 2011). Moreover, these results are in accordance with previous ones reporting an increase of OsHV-1 DNA detection and low mortality rates in oysters belonging to a low susceptible family (Segarra et al., 2014b). Although they are infected, some Pacific oyster appear to be able to manage the viral replication and to recover (He et al., 2015). The results reported in the present study suggested that injecting a viral suspension containing a low number of OsHV-1 DNA copies could be an useful tool to better understand the infection processes and how oysters are able to manage the viral infection. Recently PaulPont et al. (2015), demonstrated that a sufficient initial dose of viral particles is needed to induce high mortalities in Pacific oysters.

In this study, results showed viral RNA detection in connective tissue of different organs including mantle and gills. These organs were previously detected positive for viral DNA in naturally infected spat and adult oysters (Arzul et al., 2002). Mantle and 
gills appeared as target organs (table 2). These results were consistent with previous epidemiological studies (Arzul et al., 2002; Pepin et al., 2008; Sauvage et al., 2009). Viral RNA was detected at $14 \mathrm{hpi}$ principally in mantle and heart, by ISH using the ORF 7 probe. This result is in agreement with a previous study that detected viral transcripts before 26 hpi based on real-time PCR (Segarra et al., 2014a). However, the ORF 87 probe did not allow detection of viral transcripts on histological section before 28 hpi. Differences in probe sensitivity could explain such differences. The adductor muscle was detected positive at the final collection (28 hpi) even though the infection was performed by injection of the viral suspension in the hemolymphatic sinus of this organ. This result suggested that the adductor muscle is not an early site of viral replication. Miller et al. (2005) showed that the dissemination of Simian Immunodeficiency Virus infection to systemic lymphoid tissues occurred within 1-3 days of vaginal inoculation, although virus production at this site was established later.

The heart also appeared to be an organ of interest in terms of viral replication. Viral DNA and RNA were detected as early as $10 \mathrm{hpi}$ and $14 \mathrm{hpi}$ in this organ, respectively. The heart of Crassostrea gigas was previously described as infected by OsHV-1 (Arzul et al., 2002; Lipart and Renault, 2002). Results from the present study suggested that this organ could be a site of early replication of the virus and may play a key role in virus spread in the entire oyster body through hemolymph. Schikorski et al. (2011) reported viral DNA detection by real-time PCR in circulating hemocytes collected during an experimental infection of Pacific oyster spat. They suggested that the virus might penetrate rapidly in the hemolymphatic system, an open circulatory system in oysters (Schikorski et al., 2011). Moreover, labeled cells interpreted as circulating hemocytes were also detected in the root of the aorta in the present study. 
274 The injection of viral suspension in the hemolympathic sinus of adductor muscle

275 might allow the virus to reach rapidly the heart via hemolymph. Li et al. (1994)

276 showed leukocytes are primary targets of the causative agent of Marek's disease, an

277 Alphaherpesvirus. Moreover, leukocytes have been recognized as sites of latency in

278 bovine herpesvirus type 1 (Mweene et al., 1996), in the rabbit model of herpes

279 simplex virus type 1 (Seto et al., 1997) and in equid herpesvirus-1 (Edington et al., 280 1994; Welch et al., 1992). In this context, another study focus on the heart should be 281 investigated in order to know if this organ could be considered as a first site of viral

replication after the entry of the viral. Viral replication in heart cells might be a source of viral particle release. Infectious particles might be then transported to other organs including the adductor muscle and tissues by hemolymph.

No viral RNA detection was observed in gonad from oysters receiving the highest viral dose $(\mathrm{H})$ suggesting there was not viral replication in this organ. Nevertheless, viral DNA was detected in the gonad of oysters. Viral DNA and proteins have been previously detected in gonads of adult oysters (Arzul et al., 2002).

To conclude, this study allowed localizing OsHV-1 DNA and RNA in several organs. Viral DNA and viral replication were mainly observed in mantle, gills and heart in oysters receiving the highest viral dose $(\mathrm{H})$. However, we did not observed viral RNA by ISH in animals infected with the lowest viral dose (L). A real-time PCR based study should be performed in different organs to detect OsHV-1 DNA and RNA in order to further define target organs and tissues in oysters. 
297 Competing interests: This work was supported by Ifremer (Institut Français pour 298 l'Exploitation de la Mer). The authors declare that they have no competing interests.

299

\section{Acknowledgement}

301 The authors wish to thank the Ifremer hatchery team in La Tremblade for the 302 production of Pacific oysters. This work was supported by the EU funded project 303 Bivalife (PF7, $n^{\circ}$ 266157), the project MOLTRAQ (ERA NET EMIDA) and the Region 304 Poitou-Charentes. Thanks to M.A Travers and B. Morga for their comments and 305 suggestions on the manuscript.

306

307

308 
309 Table 1: Detection of ostreid herpesvirus 1 in highly infected Pacific oyster spat by 310 real-time PCR and ISH according the organ analysed at $2 \mathrm{hpi}, 6 \mathrm{hpi}, 10 \mathrm{hpi}, 14 \mathrm{hpi}$ 311 and 28 hpi "+++": indicates high intensity signal; "++": medium intensity signal; "+": 312 low intensity signal; "-“" no signal observed. /: tissue not observed on the histological 313 section. a. number of viral DNA copies/ng of total DNA (based on a sample of the 314 mantle). nd: no data.

\begin{tabular}{|c|c|c|c|c|c|c|c|c|c|c|c|c|c|c|c|c|c|c|c|c|}
\hline \multirow[t]{3}{*}{$\begin{array}{c}\text { Time } \\
\text { (hpii) }\end{array}$} & \multirow[t]{3}{*}{ Oysters } & \multirow[t]{3}{*}{$\mathrm{qPCR}^{\mathrm{a}}$} & \multirow{2}{*}{\multicolumn{18}{|c|}{$\begin{array}{l}\text { In situ hybridization } \\
\text { RNA (ORF 7) }\end{array}$}} \\
\hline & & & & & & & & & & & & & & & & & & & & \\
\hline & & & 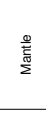 & $\frac{\underline{\underline{w}}}{\overline{\bar{\sigma}}}$ & 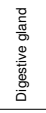 & 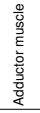 & 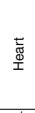 & $\begin{array}{l}\text { 芯 } \\
\text { 范 }\end{array}$ & 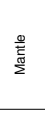 & $\frac{\underline{\underline{\underline{\omega}}}}{\overline{\bar{\sigma}}}$ & 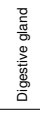 & 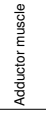 & $\begin{array}{l}\text { 志 } \\
\text { 空 }\end{array}$ & 总 & 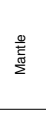 & $\frac{\underline{\underline{\omega}}}{\overline{\bar{\sigma}}}$ & 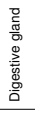 & 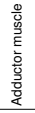 & 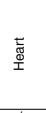 & 兽 \\
\hline \multirow{4}{*}{2} & $\begin{array}{l}1 \\
2 \\
3\end{array}$ & 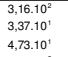 & 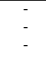 & $:$ & 5 & $:$ & $\begin{array}{l}1 \\
1 \\
1\end{array}$ & $\begin{array}{l}! \\
!\end{array}$ & 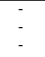 & 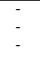 & $\therefore$ & - & 1 & ! & 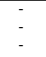 & : & 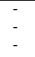 & : & $\begin{array}{l}31 \\
1 \\
1\end{array}$ & ! \\
\hline & $\begin{array}{l}3 \\
4 \\
5\end{array}$ & 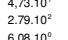 & $\therefore$ & & & & I & i & $\therefore$ & $:$ & 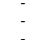 & & I & i & $:$ & $:$ & $\therefore$ & $:$ & I & i \\
\hline & $\begin{array}{l}5 \\
6 \\
7\end{array}$ & $\begin{array}{l}-, 069.10^{1} \\
2,1,10.10^{4}\end{array}$ & $\therefore$ & $\therefore$ & $\div$ & $\therefore$ & $i$ & & $\therefore$ & - & - & $\because$ & i & $!$ & $\therefore$ & $\therefore$ & $\therefore$ & $\therefore$ & $i$ & \\
\hline & 8 & $\begin{array}{l}9,00.10^{3} \\
8020^{3}\end{array}$ & - & . & 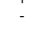 & - & i & - & - & & $\because$ & : & i & - & $\therefore$ & $\because$ & & 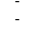 & 1 & 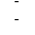 \\
\hline \multirow[t]{3}{*}{6} & $\begin{array}{l}9 \\
10\end{array}$ & 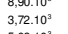 & + & $\therefore$ & $\therefore$ & - & 1 & $\therefore$ & $\therefore$ & $:$ & $\because$ & $\because$ & 1 & $\because$ & $\because$ & - & - & $:$ & 1 & $=$ \\
\hline & $\begin{array}{l}11 \\
12 \\
12\end{array}$ & 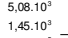 & & $\therefore$ & $\therefore$ & - & $\begin{array}{l}1 \\
1\end{array}$ & ! & $\therefore$ & $\therefore$ & $\therefore$ & - & $\begin{array}{l}1 \\
1 \\
1\end{array}$ & $!$ & $\therefore$ & $\because$ & $\therefore$ & $\because$ & $\begin{array}{l}1 \\
1\end{array}$ & 1 \\
\hline & $\begin{array}{l}13 \\
14 \\
14\end{array}$ & 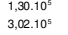 & $\begin{array}{l}+ \\
++\end{array}$ & + & $\stackrel{+}{+}$ & $:$ & $\begin{array}{l}+ \\
++ \\
+\end{array}$ & $\therefore$ & 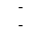 & 5 & $\therefore$ & - & - & $\vdots$ & $:$ & - & - & - & : & : \\
\hline \multirow[t]{2}{*}{10} & $\begin{array}{l}15 \\
16 \\
17 \\
18\end{array}$ & 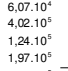 & $\begin{array}{c}\text { nd } \\
+++ \\
- \\
++ \\
++\end{array}$ & $\begin{array}{l}\text { nd } \\
+\end{array}$ & $\begin{array}{l}\text { nd } \\
+ \\
\vdots \\
\end{array}$ & $\begin{array}{c}\text { nd } \\
\vdots \\
\end{array}$ & $\begin{array}{c}\text { nd } \\
1 \\
1 \\
1 \\
\end{array}$ & $\begin{array}{l}\text { nd } \\
+\end{array}$ & $\begin{array}{c}\text { nd } \\
\vdots \\
\vdots \\
\end{array}$ & $\begin{array}{l}\text { nd } \\
\vdots \\
\vdots\end{array}$ & $\begin{array}{l}\text { nd } \\
:- \\
-\end{array}$ & $\begin{array}{c}\text { nd } \\
\vdots \\
\vdots\end{array}$ & $\begin{array}{l}\text { nd } \\
1 \\
1 \\
1\end{array}$ & $\begin{array}{l}\text { nd } \\
\vdots \\
-\end{array}$ & $\begin{array}{l}\text { nd } \\
\vdots \\
\vdots\end{array}$ & $\begin{array}{l}\text { nd } \\
:\end{array}$ & nd & $\begin{array}{l}\text { nd } \\
:\end{array}$ & $\begin{array}{c}\text { nd } \\
1 \\
1 \\
1\end{array}$ & nd \\
\hline & $\begin{array}{l}199 \\
20\end{array}$ & $\begin{array}{l}2,79.1 .1)^{5} \\
7,34.1^{5}\end{array}$ & $\begin{array}{l}+++ \\
+++\end{array}$ & $\begin{array}{l}++ \\
++\end{array}$ & $\begin{array}{l}+ \\
++ \\
++\end{array}$ & : & $\begin{array}{l}1 \\
+++\end{array}$ & ! & $\begin{array}{l}+ \\
+\end{array}$ & 5 & : & : & $\begin{array}{c}1 \\
+++\end{array}$ & $!$ & : & : & 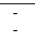 & : & ! & $!$ \\
\hline \multirow[t]{4}{*}{14} & 21 & $\begin{array}{r}5,39.10^{5} \\
3.110^{5}\end{array}$ & ++ & + & + & - & + & 1 & ++ & & & - & ++ & 1 & & & & & & I \\
\hline & $\begin{array}{l}22 \\
223 \\
24\end{array}$ & $\begin{array}{l}3.111 .10^{8} \\
6.48 .10^{5}\end{array}$ & ${ }_{n d}^{++}$ & $\begin{array}{l}+ \\
\text { nd }\end{array}$ & nd & nd & nd & nd & nd & nd & nd & nd & nd & nd & nd & nd & nd & nd & nd & nd \\
\hline & $\begin{array}{l}24 \\
25\end{array}$ & 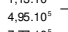 & $\frac{t+t+}{t++}$ & $\frac{++}{++}$ & + & ++ & $\frac{t+}{++}$ & $i$ & $\frac{1+4}{+t+}$ & ++ & & 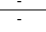 & $\frac{1++}{++}$ & $i$ & ++ & + & - & + & ++ & $i$ \\
\hline & $\begin{array}{l}26 \\
27 \\
27\end{array}$ & $\begin{array}{l}7,7,1.10^{5} \\
1,22 \cdot 10^{8}\end{array}$ & $\begin{array}{c}++ \\
+++\end{array}$ & $\begin{array}{l}+++ \\
++\end{array}$ & +; & $\begin{array}{l}+ \\
+ \\
++\end{array}$ & $\stackrel{++}{\prime}$ & $\stackrel{++}{++}$ & $\begin{array}{l}+++ \\
+++\end{array}$ & $\begin{array}{l}++ \\
+++\end{array}$ & $\begin{array}{l}+ \\
++\end{array}$ & $\begin{array}{l}++ \\
++ \\
+\end{array}$ & ; & : & + & + & ++ & & - & \\
\hline \multirow{2}{*}{28} & ${ }_{29}^{28}$ & $\begin{array}{c}\mathrm{nd} \\
1,06.11^{8}\end{array}$ & $\begin{array}{l}+++ \\
+++\end{array}$ & ${ }_{+++}^{+++}$ & $\begin{array}{l}+ \\
++\end{array}$ & $\stackrel{++}{++}$ & $\begin{array}{l}1 \\
+++\end{array}$ & + & $\begin{array}{l}+++ \\
+++\end{array}$ & $\stackrel{++}{++}$ & + & $\stackrel{++}{++}$ & $\frac{1}{+++}$ & : & $\stackrel{++}{++}$ & $\stackrel{++}{++}$ & & $\therefore$ & ${ }_{+++}^{1}$ & \\
\hline & 30 & $3,15.10^{5}$ & ${ }^{+++}$ & ${ }^{+++}$ & ++ & ++ & I & + & +++ & +++ & ${ }^{++}$ & & & & ++ & ${ }^{++}$ & & & 1 & - \\
\hline $\begin{array}{l}\text { indifichal } \\
\text { postives }\end{array}$ & & & $16 / 28$ & 1328 & 111/28 & $6 / 28$ & 89 & $6 / 19$ & 10/28 & $7 / 28$ & $4 / 28$ & $4 / 28$ & $5 / 9$ & $a_{119}$ & $5 / 28$ & 528 & $1 / 28$ & $3 / 28$ & $2 / 9$ & 0/19 \\
\hline $\begin{array}{c}\text { Positives } \\
\%\end{array}$ & & & 57 & 46 & 39 & 18 & 89 & 32 & 36 & 25 & 14 & 14 & 55 & 0 & 18 & ${ }_{18}$ & 4 & ${ }_{11}$ & 22 & 。 \\
\hline
\end{tabular}


320 Table 2: Contrast statement's test between tissues of Crassostrea gigas for each 321 probe (DNA, RNA ORF 7 and RNA ORF 87). The infection level of ostreid

322 herpesvirus 1 detected by ISH was compared in different tissues (adductor muscle, 323 mantle, digestive gland, gonad, heart and gills). Significant differences were noted in 324 bold $(p<0.05)$.

\begin{tabular}{|l|r|r|r|}
\cline { 2 - 4 } \multicolumn{1}{c|}{ Contrast } & \multicolumn{3}{c|}{$p$ value } \\
\hline C1 Adductor muscle/ Mantle & DNA & RNA (ORF 7) & RNA (ORF 87) \\
C2 Digestive gland/ Mantle & $\mathbf{0}$ & $\mathbf{0}$ & 0.062 \\
C3 Gills/ Mantle & $\mathbf{0}$ & $\mathbf{0}$ & $\mathbf{0 . 0 0 7}$ \\
C4 Gonad/ Mantle & $\mathbf{0 . 0 0 2}$ & $\mathbf{0 . 0 3 2}$ & 0.415 \\
C5 Heart/ Mantle & $\mathbf{0}$ & $\mathbf{0}$ & $\mathbf{0 . 0 1 2}$ \\
C6 Adductor muscle/ Heart & 0.234 & 0.407 & 0.94 \\
C7 Digestive gland/ Heart & $\mathbf{0}$ & $\mathbf{0 . 0 0 1}$ & 0.139 \\
C8 Gills/ Heart & $\mathbf{0 . 0 0 1}$ & $\mathbf{0}$ & $\mathbf{0 . 0 2 2}$ \\
C9 Gonad/ Heart & 0.163 & $\mathbf{0 . 0 1 6}$ & 0.553 \\
C10 Adductor muscle/ Gonad & $\mathbf{0}$ & 0 & $\mathbf{0 . 0 3 2}$ \\
C11 Digestive gland/ Gonad & 0.668 & 0.073 & 0.273 \\
C12 Gills/ Gonad & 0.087 & 0.177 & 0.902 \\
C13 Adductor muscle/ Gills & $\mathbf{0}$ & $\mathbf{0 . 0 0 2}$ & $\mathbf{0 . 0 4 7}$ \\
C14 Digestive gland/ Gills & $\mathbf{0}$ & 0.058 & 0.241 \\
C15 Adductor muscle/ Digestive gland & $\mathbf{0 . 0 1 2}$ & $\mathbf{0 . 0 1 7}$ & $\mathbf{0 . 0 3 1}$ \\
\hline
\end{tabular}


Figure 1: Survival of Crassostrea gigas spat oysters during an experimental infection with two OsHV-1 doses. $\mathrm{H}$ : High dose $\left(10^{6}\right.$ copies of viral DNA/ $\left.\mu \mathrm{L}\right)$ and L: Low dose $\left(10^{1}\right.$ copies of viral $\left.\mathrm{DNA} / \mu \mathrm{L}\right) . \mathrm{n}=10$ oysters/condition.

Figure 2: Viral DNA detection curves by real time quantitative PCR in spat oysters. Average $\mathrm{n}=6$ per condition. Error bars represent standard error of the mean (SEM).

Figure 3: Absence of viral detection by in situ hybridization for lowly infected oysters ( $L$ dose) at 26 hpi using viral DNA probe in mantle connective tissue.

Figures 4. Detection of viral DNA by in situ hybridization (ISH) in experimentally infected spat 14 hpi ( $\mathrm{H}$ dose). Positive results are characterized by brown/black precipitates (arrows). Fig. 4a: positive cells in mantle connective tissue. Fig. 4b: positive muscular cells in the heart ventricle. Fig. 4c: positive cells (hemocytes) in a hemolymph sinus. Fig 4d: positive cell in gonad connective tissue.

Figures 5. In situ hybridization probe ORF 7 (complementary to viral mRNA) binding specifically (discrete labelling of cells: arrows) to OsHV-1 mRNA gene 7 (gene encoding an SF2 helicase) in mantle connective tissue at $28 \mathrm{hpi}(\mathrm{H}$ dose). 
Arzul, I., Renault, T., Thébault, A., Gérard, A., 2002. Detection of oyster herpesvirus DNA and proteins in asymptomatic Crassostrea gigas adults. Virus Res. 84, 151-160.

Barbosa-Solomieu, V., Miossec, L., Vázquez-Juárez, R., Ascencio-Valle, F., Renault, T., 2004. Diagnosis of Ostreid herpesvirus 1 in fixed paraffin-embedded archival samples using PCR and in situ hybridisation. J. Virol. Methods 119, 65-72. doi:10.1016/j.jviromet.2004.02.007

Biesaga, B., Szostek, S., Klimek, M., Jakubowicz, J., Wysocka, J., 2012. Comparison of the sensitivity and specificity of real-time PCR and in situ hybridization in HPV16 and 18 detection in archival cervical cancer specimens. Folia Histochem. Cytobiol. 50, 239247. doi:10.5603/FHC.2012.0033

Burge, C.A., Friedman, C.S., 2012. Quantifying Ostreid Herpesvirus (OsHV-1) Genome Copies and Expression during Transmission. Microb. Ecol. 63, 596-604. doi:10.1007/s00248-011-9937-1

Chaves, A.J., Busquets, N., Campos, N., Ramis, A., Dolz, R., Rivas, R., Valle, R., Abad, F.X., Darji, A., Majo, N., 2011. Pathogenesis of highly pathogenic avian influenza A virus (H7N1) infection in chickens inoculated with three different doses. Avian Pathol. J. WVPA 40, 163-172. doi:10.1080/03079457.2011.551874

Corbeil, S., Faury, N., Segarra A., Renault T., 2015. Development of an in situ hybridization assay for the detection of ostreid herpesvirus type 1 mRNAs in the Pacific oyster, Crassostrea gigas. Journal Of Virological Methods, 211, 43-50. doi: 10.1016/j.jviromet.2014.10.007

Davison, A.J., Trus, B.L., Cheng, N., Steven, A.C., Watson, M.S., Cunningham, C., Le Deuff, R.-M., Renault, T., 2005. A novel class of herpesvirus with bivalve hosts. J. Gen. Virol. 86, 41-53. doi:10.1099/vir.0.80382-0

Edington, N., Welch, H.M., Griffiths, L., 1994. The prevalence of latent Equid herpesviruses in the tissues of 40 abattoir horses. Equine Vet. J. 26, 140-142.

Garcia, C., Thébault, A., Dégremont, L., Arzul, I., Miossec, L., Robert, M., Chollet, B., François, C., Joly, J.-P., Ferrand, S., Kerdudou, N., Renault, T., 2011. Ostreid herpesvirus 1 detection and relationship with Crassostrea gigas spat mortality in France between 1998 and 2006. Vet. Res. 42, 73. doi:10.1186/1297-9716-42-73

He, Y., A. Jouaux, S. E. Ford, C. Lelong, P. Sourdaine, M. Mathieu and X. M. Guo. 2015. Transcriptome analysis reveals strong and complex antiviral response in a mollusc. Fish Shellfish Immunol., 46, 131-144.

Huang, C., Zhang, X., Gin, K.Y.., Qin, Q.W., 2004. In situ hybridization of a marine fish virus, Singapore grouper iridovirus with a nucleic acid probe of major capsid protein. J. Virol. Methods 117, 123-128. doi:10.1016/j.jviromet.2004.01.002

Jones, C., 2003. Herpes Simplex Virus Type 1 and Bovine Herpesvirus 1 Latency. Clin. Microbiol. Rev. 16, 79-95. doi:10.1128/CMR.16.1.79-95.2003

Kaplan E.L., Meier P., 1958. Non parametric estimation from incomplete observations. J Am Stat Assoc;53:457-81.

Kleeman, S.N., Adlard, R.D., 2000. Molecular detection of Marteilia sydneyi, pathogen of Sydney rock oysters. Dis. Aquat. Organ. 40, 137-146. doi:10.3354/dao040137

Landis, J.R., Koch, G.G., 1977. The Measurement of Observer Agreement for Categorical Data. Biometrics 33, 159-174. doi:10.2307/2529310

Lipart, C., Renault, T., 2002. Herpes-like virus detection in infected Crassostrea gigas spat using DIG-labelled probes. J. Virol. Methods 101, 1-10. doi:10.1016/S01660934(01)00413-X

Miller, C.J., Li, Q., Abel, K., Kim, E.-Y., Ma, Z.-M., Wietgrefe, S., Franco-Scheuch, L.L., Compton, L., Duan, L., Shore, M.D., Zupancic, M., Busch, M., Carlis, J., Wolinksy, S., Haase, A.T., 2005. Propagation and Dissemination of Infection after Vaginal Transmission of Simian Immunodeficiency Virus. J. Virol. 79, 9217-9227. doi:10.1128/JVI.79.14.9217-9227.2005 
Mweene, A.S., Okazaki, K., Kida, H., 1996. Detection of viral genome in non-neural tissues of cattle experimentally infected with bovine herpesvirus 1. Jpn. J. Vet. Res. 44, 165174.

Nichols, D. P. (1997). What kind of contrasts are these? UCLA: Statistical Consulting Group. http://www.ats.ucla.edu/stat/stata/ado/analysis/. (July 25, 2013). Originally from SPSS Keywords, Number 63, 1997.

Oden, E., Martenot, C., Berthaux, M., Travaillé, E., Malas, J.P., Houssin, M., 2011. Quantification of ostreid herpesvirus 1 (OsHV-1) in Crassostrea gigas by real-time PCR: Determination of a viral load threshold to prevent summer mortalities. Aquaculture 317, 27-31. doi:10.1016/j.aquaculture.2011.04.001

Paul-Pont I., Evans O., Dhand N.K., Whittington R.J., 2015. Experimental infections of Pacific oyster Crassostrea gigas using the Australian ostreid herpesvirus-1 (OsHV-1) $\mu$ Var strain. Dis. Aquat. Org. 113, 137-147.

Pepin, J.F., Riou, A., Renault, T., 2008. Rapid and sensitive detection of ostreid herpesvirus 1 in oyster samples by real-time PCR. J. Virol. Methods 149, 269-276.

Renault, T., Bouquet, A.L., Maurice, J.-T., Lupo, C., Blachier, P., 2014. Ostreid herpesvirus 1 infection among Pacific oysters, Crassostrea giga, spat: virus replication and circulation related to water temperature prior the onset of mortality. Appl. Environ. Microbiol. AEM.00484-14. doi:10.1128/AEM.00484-14

Renault, T., Le Deuff, R.-M., Cochennec, N., Maffart, P., 1994. Herpesviruses associated with mortalities among Pacific oyster, Crassostrea gigas, in France-Comparative study. Rev. Médicale Vét. 145, 735-742.

Renault, T., Lipart, C., 1998. Diagnosis of herpes-like virus infections in oysters using molecular techniques. Presented at the Aquaculture and water: fish culture, shellfish culture and water usage.

Sauvage, C., Pépin, J.F. O., Lapègue, S., Boudry, P., Renault, T., 2009. Ostreid herpes virus 1 infection in families of the Pacific oyster, Crassostrea gigas, during a summer mortality outbreak: Differences in viral DNA detection and quantification using realtime PCR. Virus Res. 142, 181-187.

Schikorski, D., Faury, N., Pepin, J.F., Saulnier, D., Tourbiez, D., Renault, T., 2011. Experimental ostreid herpesvirus 1 infection of the Pacific oyster Crassostrea gigas: Kinetics of virus DNA detection by q-PCR in seawater and in oyster samples. Virus Res. 155, 28-34.

Schikorski, D., Renault, T., Saulnier, D., Faury, N., Moreau, P., Pépin, J.-F., 2011. Experimental infection of Pacific oyster Crassostrea gigas spat by ostreid herpesvirus 1: demonstration of oyster spat susceptibility. Vet. Res. 42, 27. doi:10.1186/12979716-42-27

Segarra, A., Faury, N., Pépin, J.-F., Renault, T., 2014a. Transcriptomic study of 39 ostreid herpesvirus 1 genes during an experimental infection. J. Invertebr. Pathol. 119C, 511. doi:10.1016/j.jip.2014.03.002

Segarra, A., Mauduit, F., Faury, N., Trancart, S., Dégremont, L., Tourbiez, D., Haffner, P., Barbosa-Solomieu, V., Pépin, J.-F., Travers, M.-A., Renault, T., 2014b. Dual transcriptomics of virus-host interactions: comparing two Pacific oyster families presenting contrasted susceptibility to ostreid herpesvirus 1. BMC Genomics 15, 580. doi:10.1186/1471-2164-15-580

Segarra, A., Pépin, J.F., Arzul, I., Morga, B., Faury, N., Renault, T., 2010. Detection and description of a particular Ostreid herpesvirus 1 genotype associated with massive mortality outbreaks of Pacific oysters, Crassostrea gigas, in France in 2008. Virus Res. 153, 92-99. doi:10.1016/j.virusres.2010.07.011

Seto, A., Nagano, Y., Isono, T., Kurokawa, M., 1997. Resistance to herpes simplex virus type 1 and its latent infection of human T cell lymphotropic virus type I-transformed T cell lines of rabbits. J. Gen. Virol. 78 ( Pt 11), 2901-2907. 
465

466

467

468

469

470

471

472

473

474

475

476

477

478

479

480

481

482

483

484

485

486

487

488

489

490

491

492

493

494

495

496

497

498

499

500

501

Walton, A., Montanie, H., Arcier, J.M., Smith, V.J., Bonami, J.R., 1999. Construction of a gene probe for detection of $P$ virus (Reoviridae) in a marine decapod. J. Virol. Methods 81, 183-192.

Wang, H.-W., Sharp, T. V., Koumi, A., Koentges, G., Boshoff, C., 2002. Characterization of an anti-apoptotic glycoprotein encoded by Kaposi's sarcoma-associated herpesvirus which resembles a spliced variant of human survivin. The EMBO Journal, 21(11), 2602-2615. doi:10.1093/emboj/21.11.2602

Webb, S.C., Fidler, A., Renault, T., 2007. Primers for PCR-based detection of ostreid herpes virus-1 (OsHV-1): Application in a survey of New Zealand molluscs. Aquaculture 272, 126-139. doi:10.1016/j.aquaculture.2007.07.224

Welch, H.M., Bridges, C.G., Lyon, A.M., Griffiths, L., Edington, N., 1992. Latent equid herpesviruses 1 and 4 : detection and distinction using the polymerase chain reaction and co-cultivation from lymphoid tissues. J. Gen. Virol. 73 ( Pt 2), 261-268. 


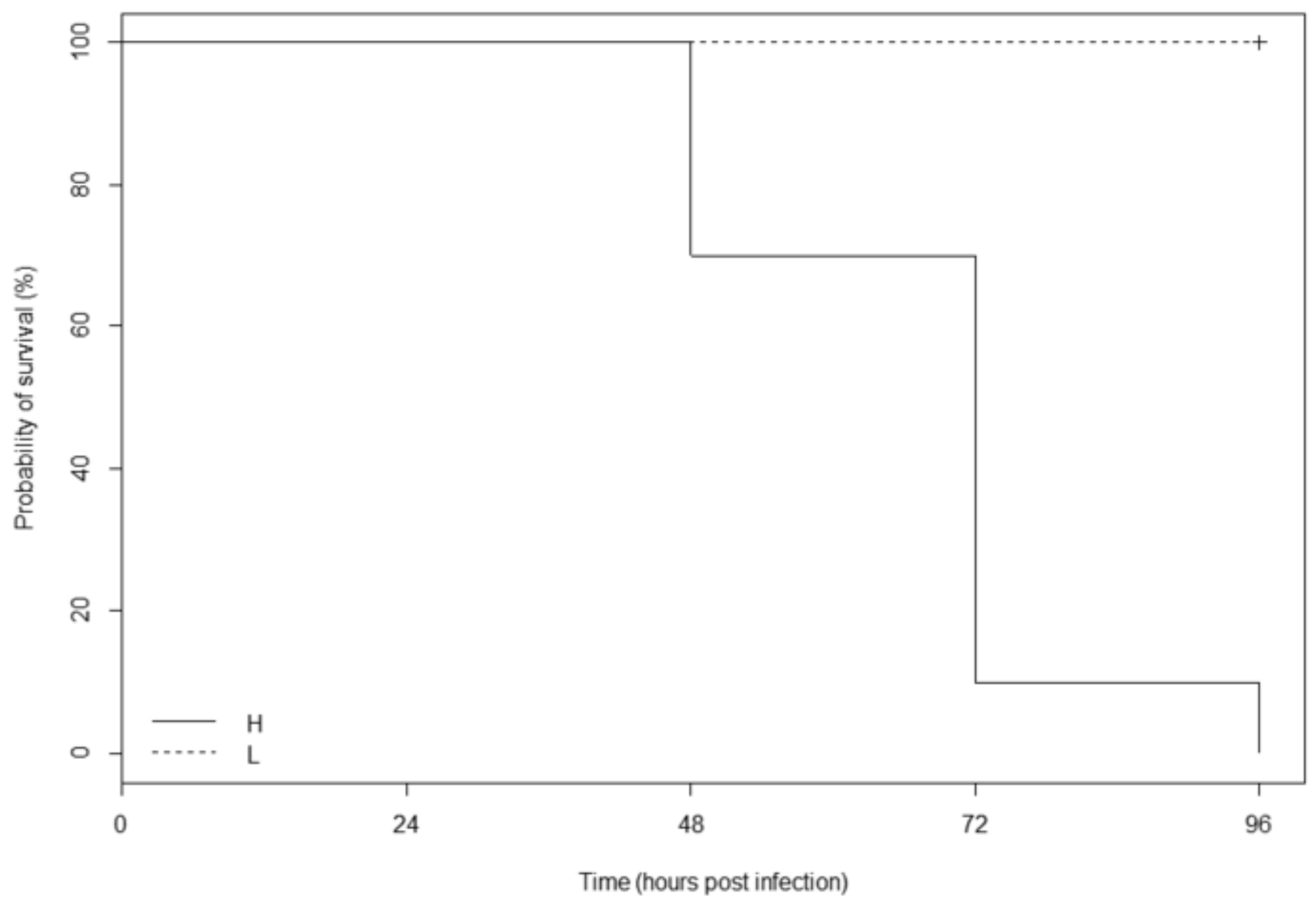




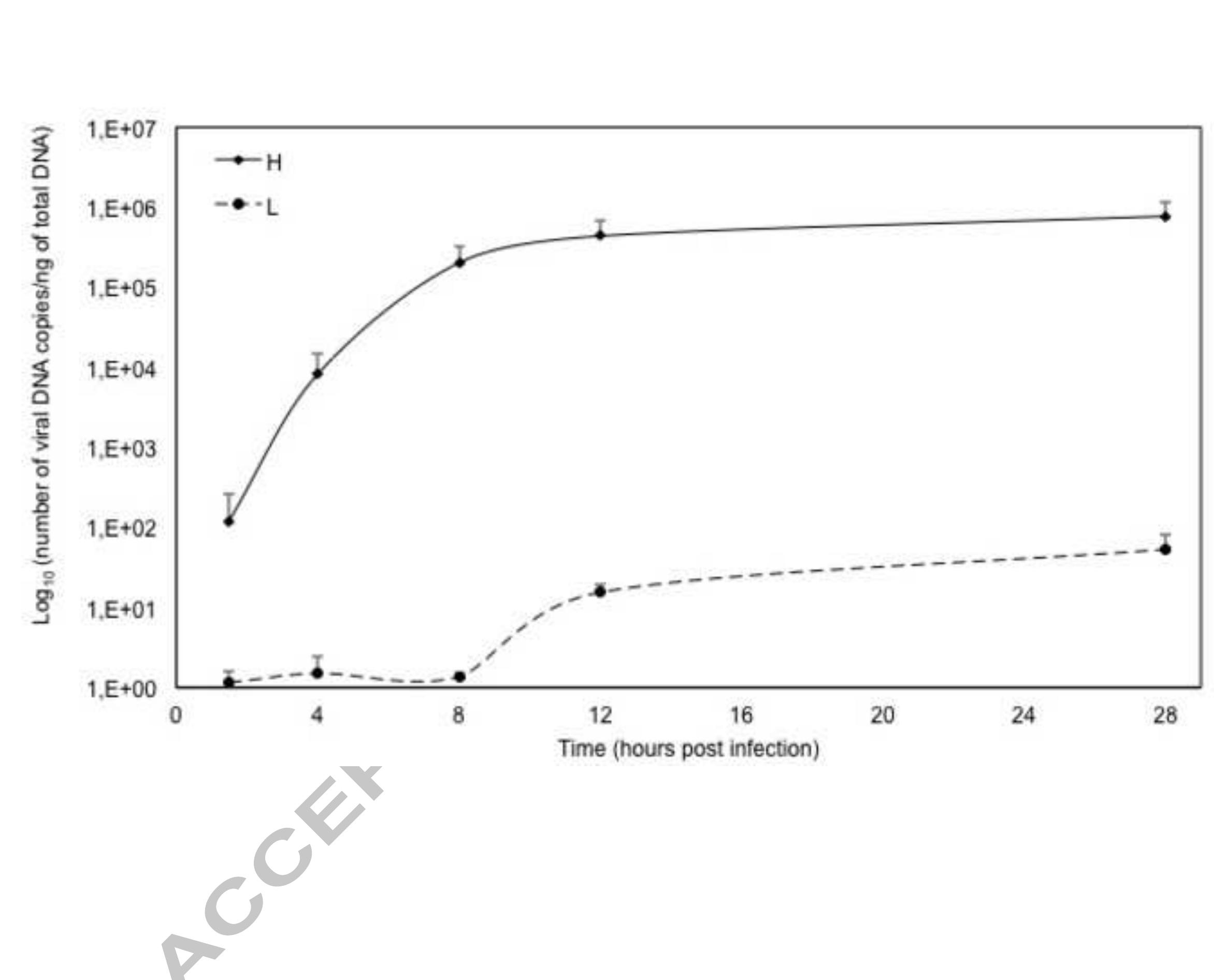

ACCEPTED MANUSCRIPT

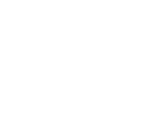

\section{ACCEPTED MANUSCRIPT}

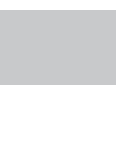

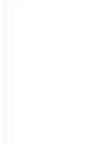

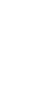

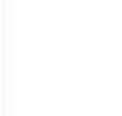

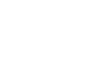




\section{Figure 3}

ACCEPTED MANUSCRIPT

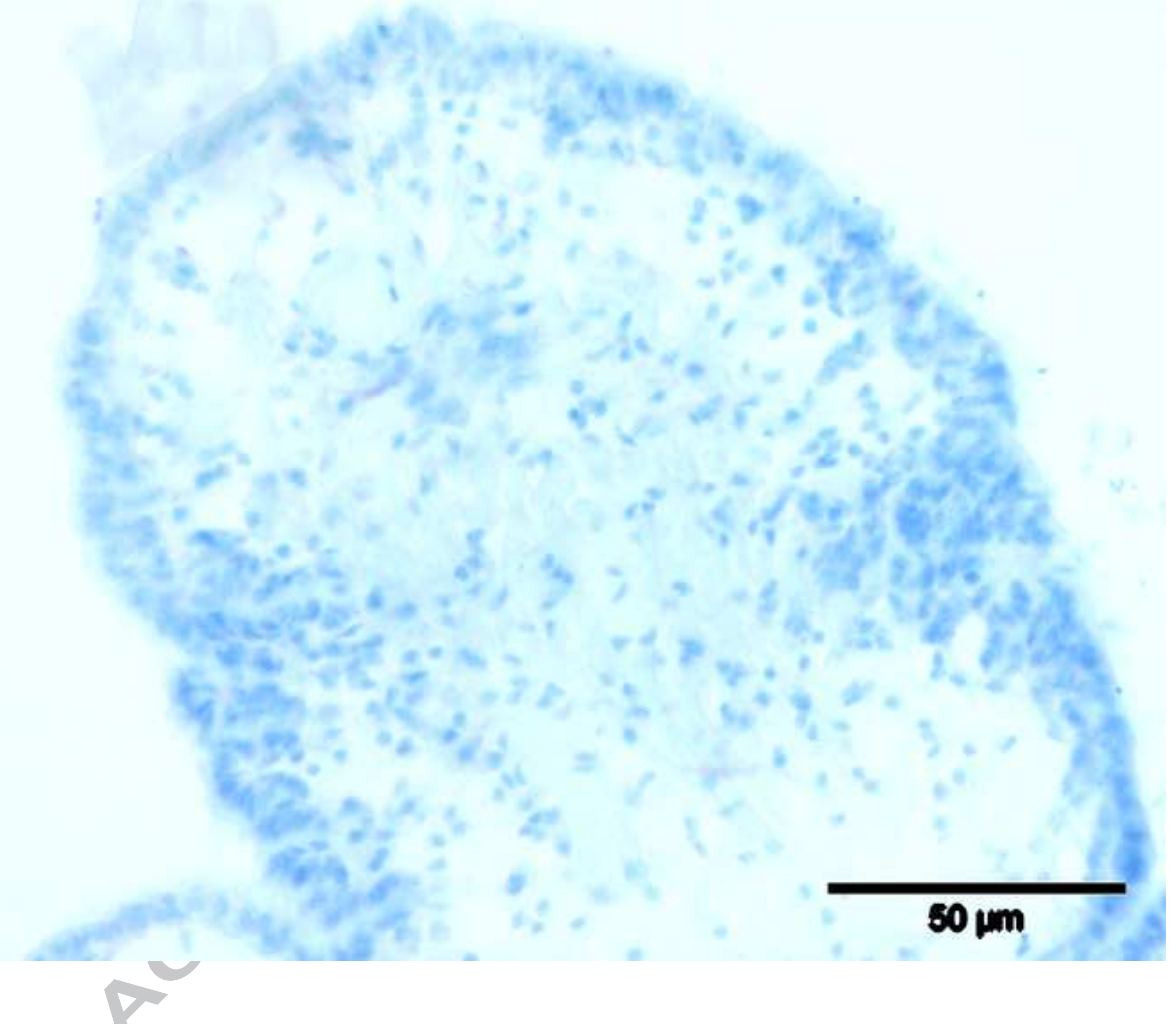


ACCEPTED MANUSCRIPT
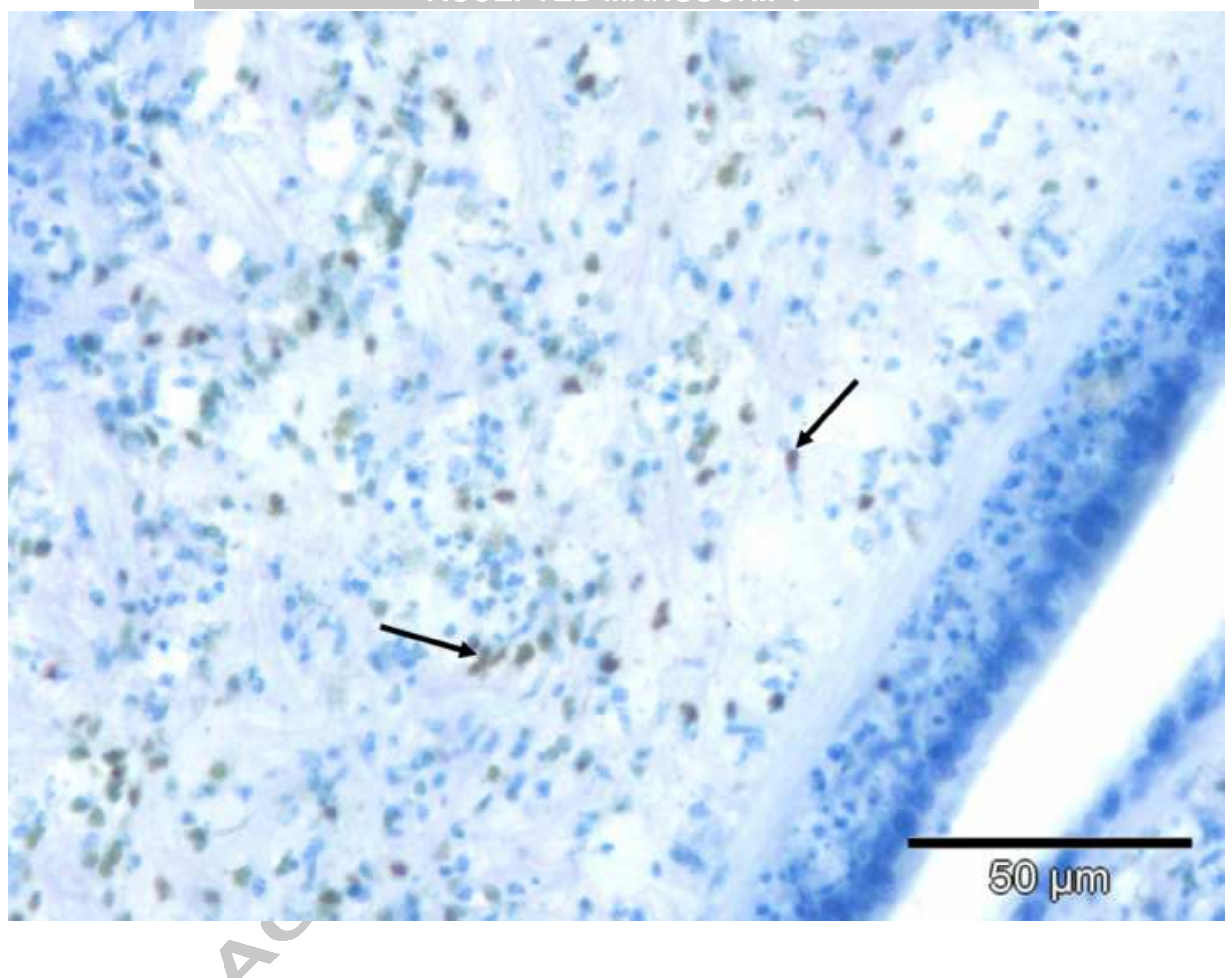


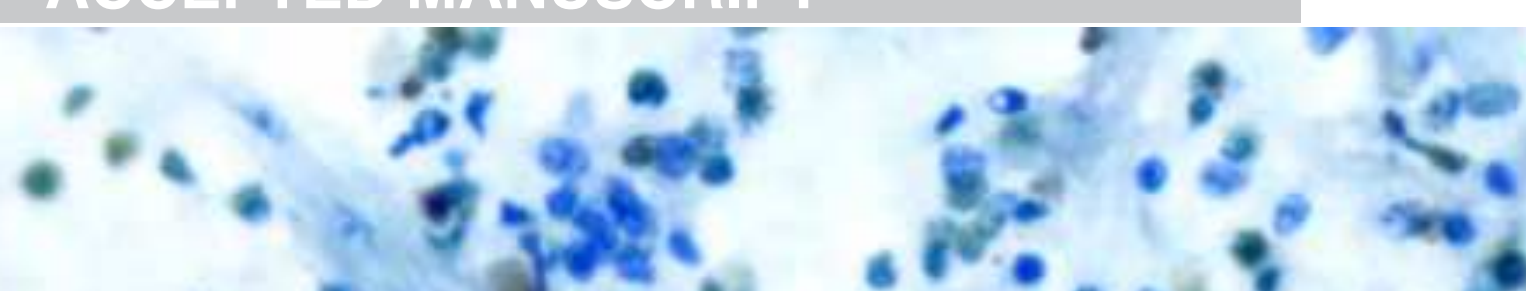

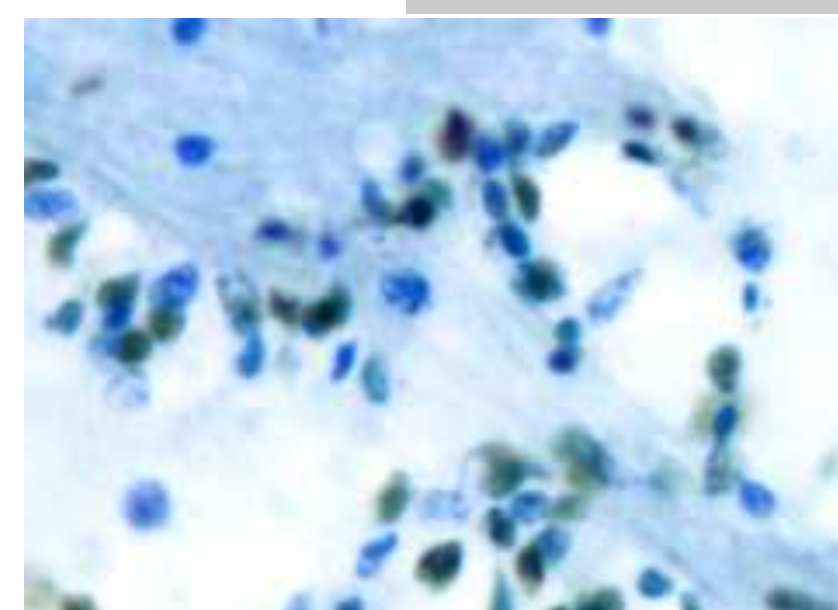

a. " $8,0,4$

$\therefore t^{2}-2.6$

$b^{4}+4=8$

\%

$\because \div \rightarrow 0$.

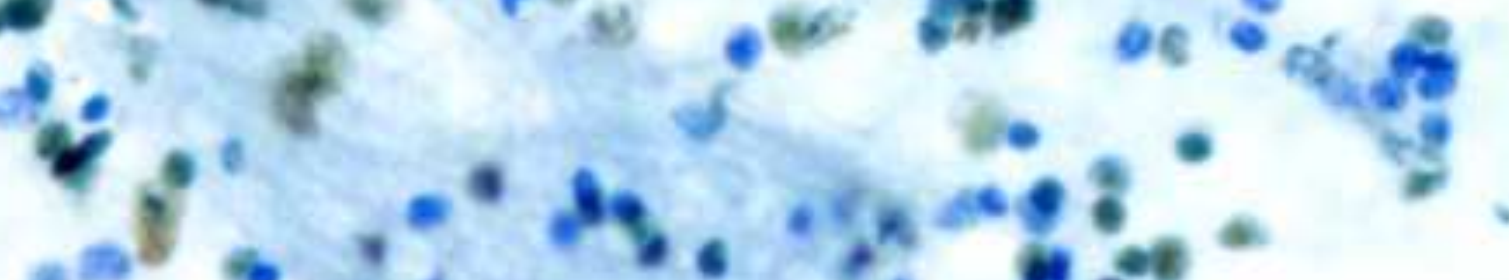
gets is is

$\rightarrow 04 \alpha$

8

:

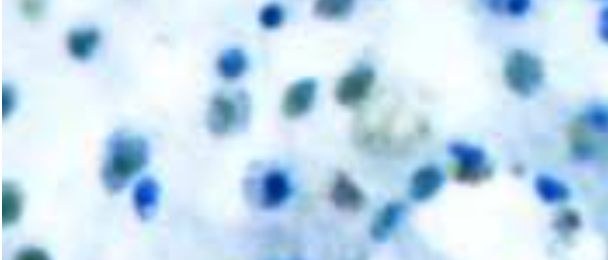

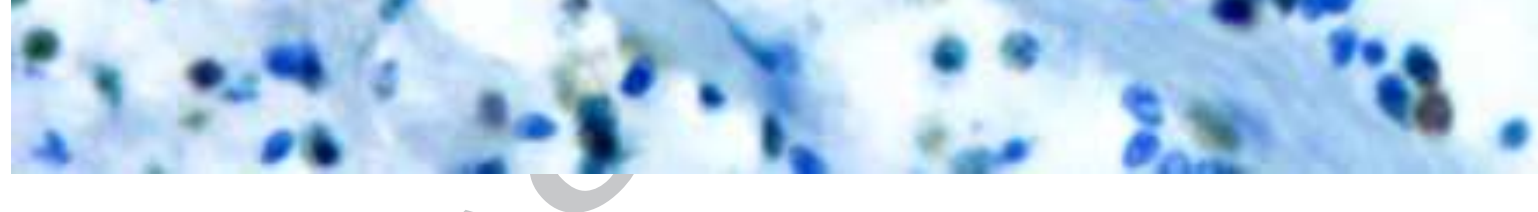

$\log ^{2} \operatorname{ton}^{4}$

, $4 y^{\circ}, \infty^{\circ}$

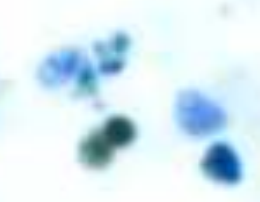

$5=-10$ -

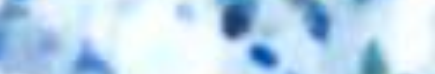
a

(1) 12, or 0

is ext -8 ale tes to.
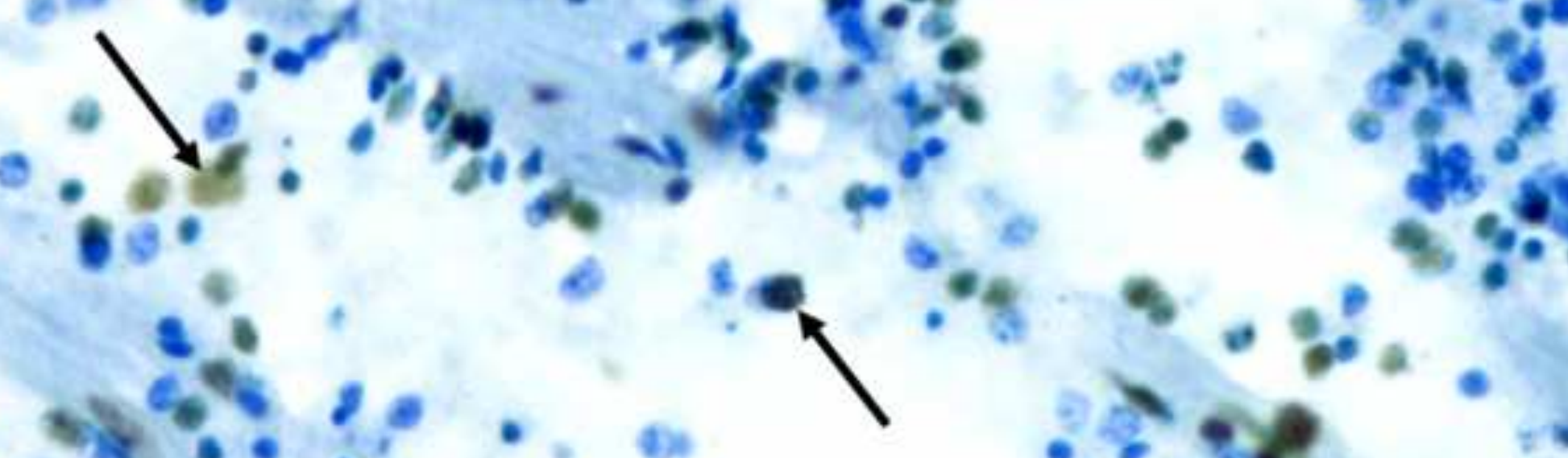

a.s. (2)

e $-3^{2}$ ex

e 8

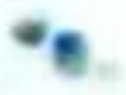

$\rightarrow 0 \mathrm{~s}$

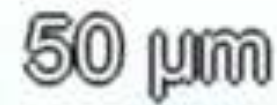

บกอ

$\nabla$ 


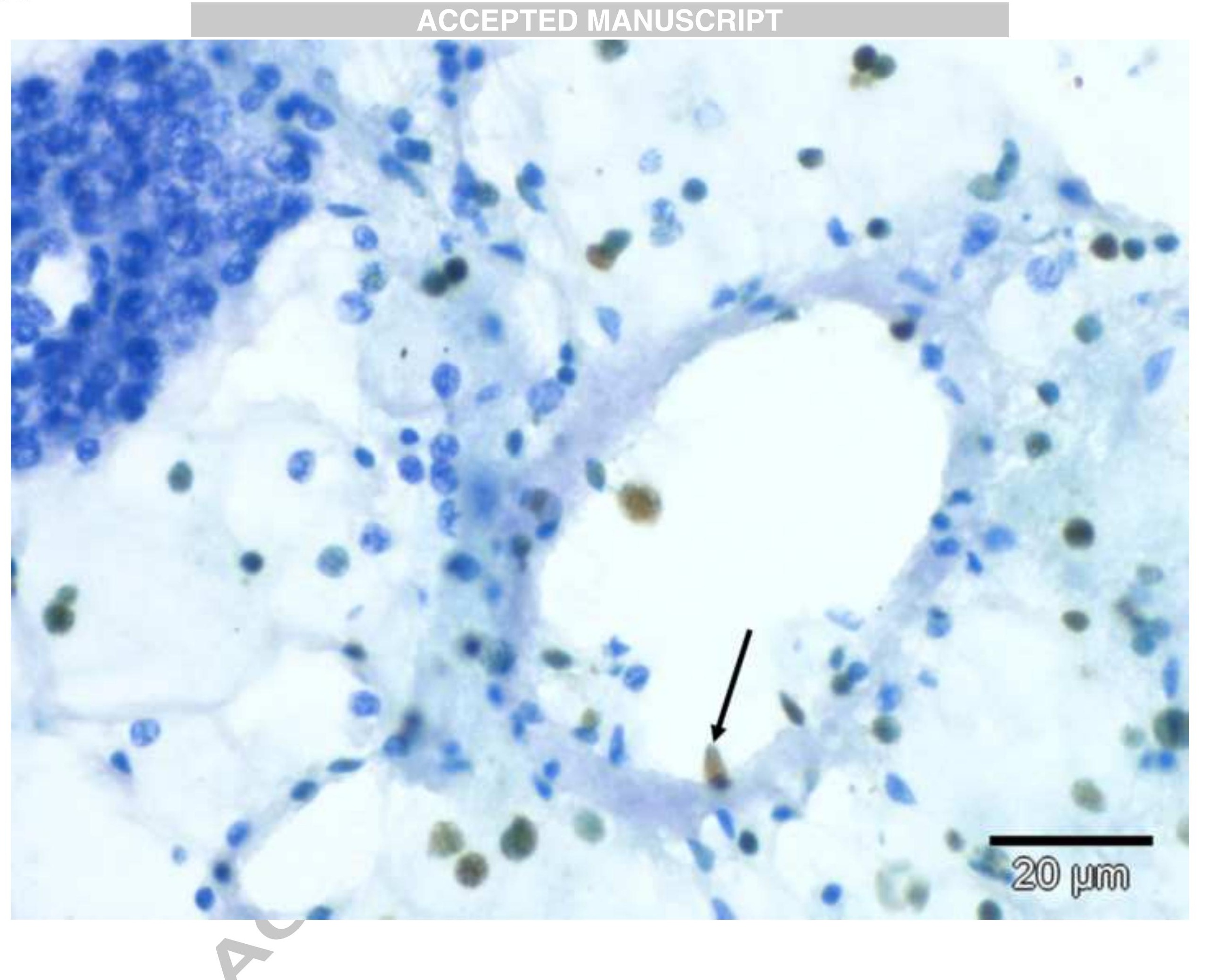




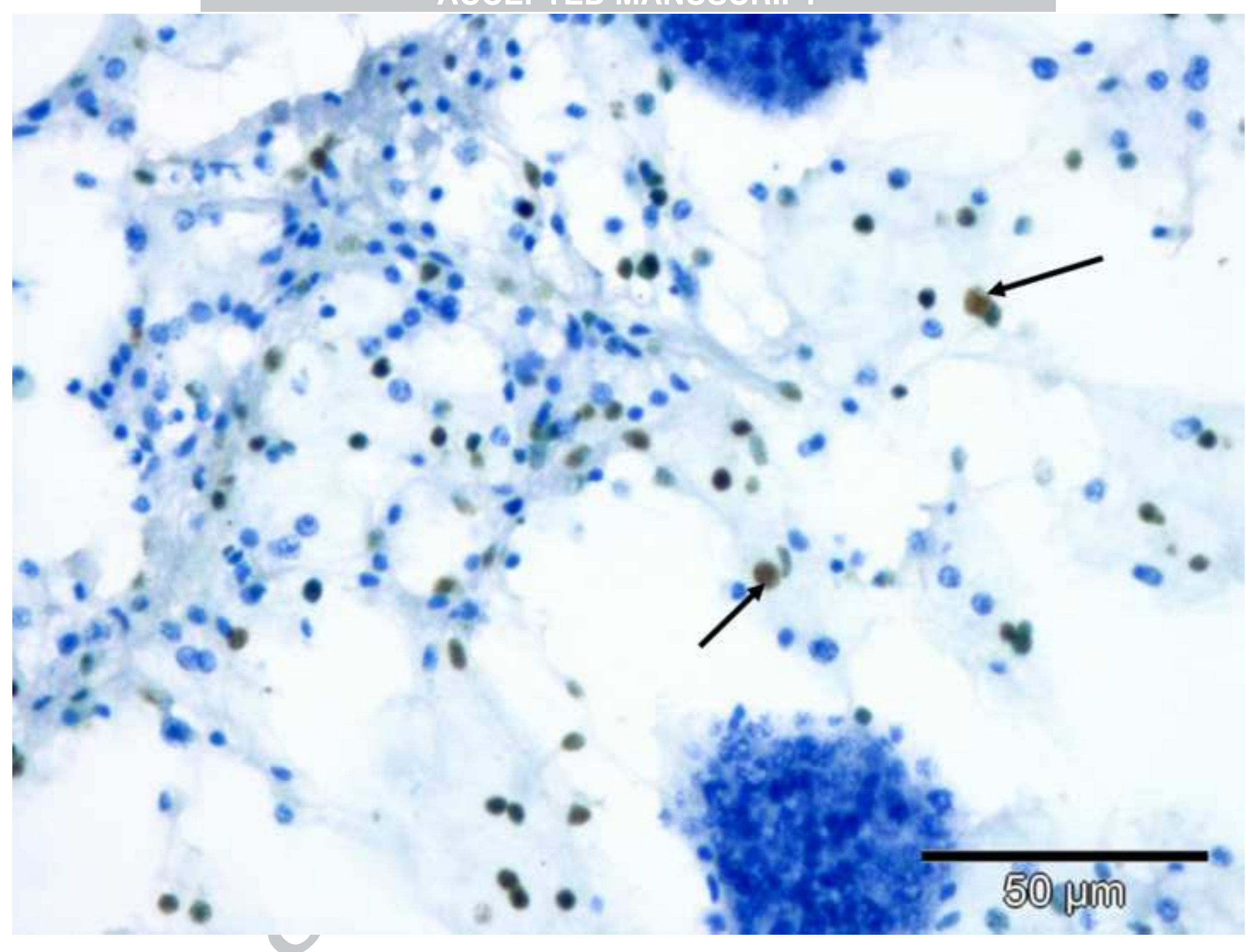

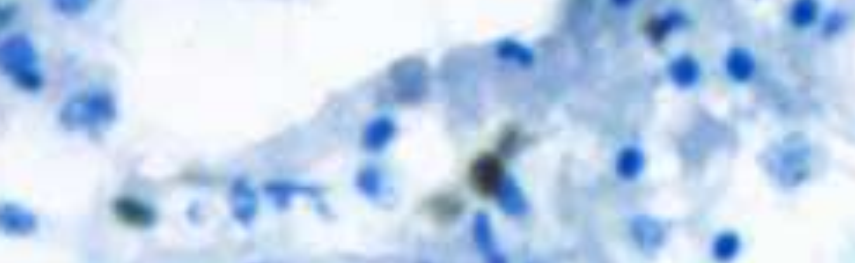

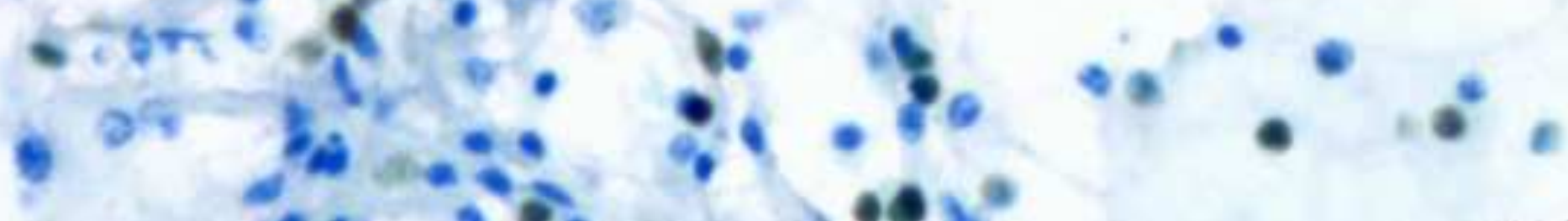

e

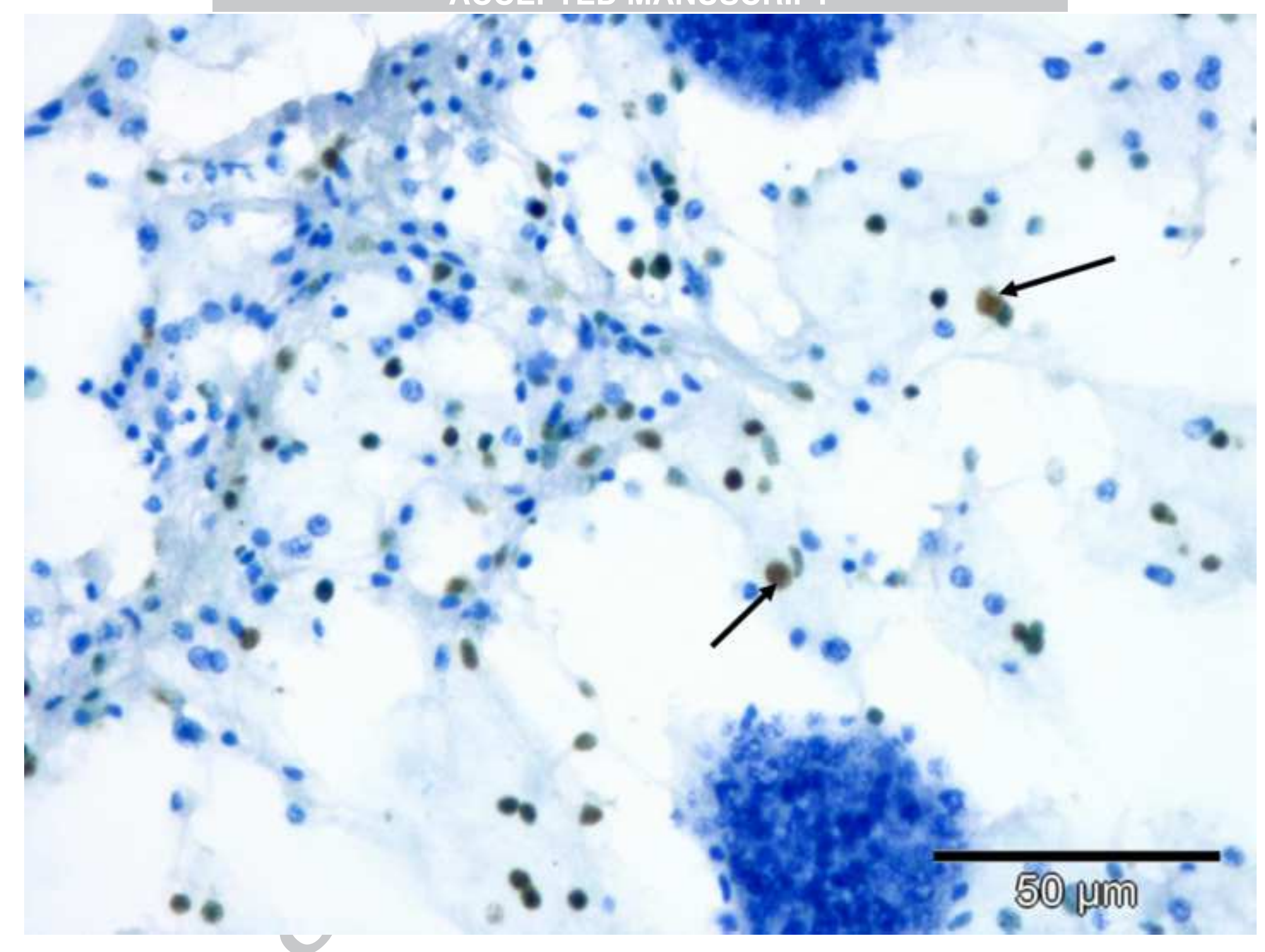



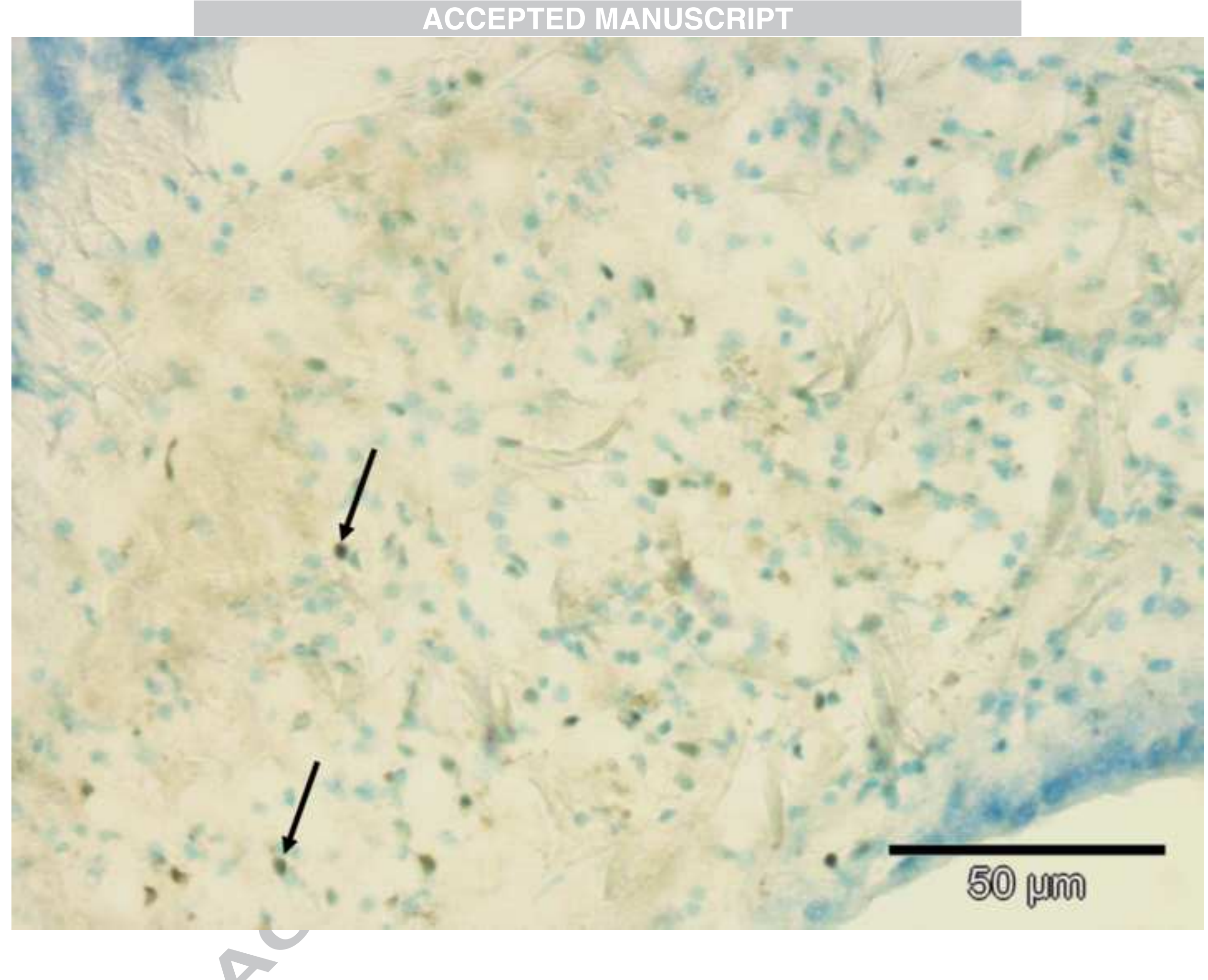